\title{
Hubungan Antara Sumber dan Metode Penghitungan Kerugian Keuangan Negara dengan Penetapan Uang Pengganti
}

\author{
Mahrus Ali \\ Fakultas Hukum Universitas Islam Indonesia \\ Jl. Tamansiswa 158 Yogyakarta \\ surham_02@yahoo.com
}

\begin{abstract}
There are two main things discussed in this research; first, the source of the state financial loss and the calculation method in the court decision of corruption case, and second,the correlation between the calculation method of the state financial loss in the legal perspective of the judges and the decision on the amount of indemnification. This research is a normative legal study. The result of the research shows that first, the source of the state financial loss varies from the asset release, fictitious activities, unsettled payables of tax payers, andout-of-budget expenses, with the calculation method used involving rounded down total loss, main loss, main loss plus interest, and the margin between the amount of the budget subtracted by the realization of the used amount. Second, in deciding the amount of the indemnification, not all of the judges referred to the calculation method of the state financial loss.
\end{abstract}

Key words : State financial loss, indemnification, corruption

\begin{abstract}
Abstrak
Ada dua permasalahan yang dikaji dalam penelitian. Pertama, sumber kerugian keuangan negara dan metode penghitungannya dalam putusan-putusan pengadilan perkara tindak pidana korupsi. Kedua, hubungan antara metode penghitungan kerugian keuangan negara dalam pertimbangan hukum hakim dengan penetapan jumlah pembayaran uang pengganti. Penelitian ini merupakan penelitian hukum normatif. Hasil penelitian menunjukkan bahwa, pertama, sumber kerugian keuangan negara bervariasi antara lain pelepasan aset, kegiatan fiktif, wajib bayar tidak setor, dan pengeluaran yang tidak sesuai anggaran, dengan metode penghitungan berupa kerugian total dengan penyesuaian ke bawah, kerugian pokok, kerugian pokok ditambah bunga, dan jumlah selisih antara anggaran dana yang seharusnya digunakan dikurangi jumlah realisasi. Kedua, dalam menetapkan jumlah uang pengganti, hakim tidak semuanya mengacu kepada metode penghitungan kerugian keuangan negara.
\end{abstract}

Kata kunci: Kerugian keuangan negara, uang pengganti, korupsi 


\section{Pendahuluan}

Persoalan yang hingga saat ini belum terdapat kesepahaman pandangan adalah apakah kerugian keuangan negara dalam Pasal 2 ayat (1) dan Pasal 3 Undang-Undang No. 31 Tahun 1999 jo Undang-Undang No. 20 Tahun 2001 tentang Pemberantasan Tindak Pidana Korupsi harus nyata adanya (actual lose) atau cukup berupa kerugian potensial (potential lose) ${ }^{1}$ Adami Chazawi menyatakan, bahwa suatu perbuatan dapat menimbulkan kerugian keuangan negara tanpa merinci dan menyebut adanya bentuk dan jumlah kerugian keuangan negara tertentu sebagaimana pada tindak pidana materiil. ${ }^{2}$ Sedangkan Nur Basuki Minarno berpendapat, bahwa kerugian keuangan negara harus berupa actual lose. Menurutnya, makna 'memperkaya' dalam rumusan Pasal 2 ayat (1) dan 'menguntungkan' dalam rumusan Pasal 3 mensyaratkan bertambahnya kekayaan atau keuntungan dari yang tidak ada menjadi ada atau dari yang sudah kaya/untung bertambah kaya/untung. ${ }^{3}$

Penghitungan kerugian keuangan negara atas dasar actual lose dan potential lose hakikatnya memunculkan dua pandangan. Pertama, pandangan yang menyatakan bahwa penghitungan kerugian keuangan negara tidak harus sama persis dengan jumlah kekayaan atau keuntungan yang diperoleh pelaku. ${ }^{4}$ Kedua, pandangan yang menyatakan bahwa penghitungan kerugian keuangan negara harus sama persis dengan jumlah kekayaan atau keuntungan yang diperoleh pelaku, karena apabila ternyata penghitungan tersebut tidak sama, maka terdakwa akan bebas. Pandangan kedua inilah yang kemudian memunculkan gagasan bahwa yang terpenting bukan jumlah kerugian keuangan negara yang pasti karena sulit menentukannya, ${ }^{5}$ tapi lebih kepada penentuan sumber dan metode dalam menghitung kerugian keuangan negara.

Dalam praktik penegakan hukum perkara tindak pidana korupsi Pasal 2 ayat (1) dan Pasal 3, Jaksa Penuntut Umum umumnya akan meminta Badan Pemeriksa

\footnotetext{
${ }^{1}$ Mahrus Ali, Asas, Teori dan Praktik Hukum Pidana Korupsi, UII Press, Yogyakarta, 2013, hlm. 106

${ }^{2}$ Adami Chazawi, Hukum Pidana Materïl dan Formil Korupsi di Indonesia, Cetk. Kedua, Bayumedia Publishing, Malang, 2005, hlm. 45

${ }^{3}$ Nur Basuki Minarno, Penyalahgunaan Wewenang dan Tindak Pidana Korupsi dalam Pengelolaan Keuangan Daerah, Cetk. Kedua, LaksBang Mediatama, Yogyakarta, 2009, hlm. 50

${ }^{4}$ Bab I ketentuan Umum Undang-Undang No. 1 Tahun 2004 tentang Perbendaharaan Negara secara jelas menyebutkan, bahwa yang dimaksud dengan kerugian keuangan negara atau daerah adalah "berkurangnya uang, surat berharga, dan barang yang nyata dan pasti jumlahnya sebagai akibat perbuatan melawan hukum baik sengaja ataupun lalai".

${ }^{5}$ Baca putusan Mahkamah Konstitusi Nomor 003/PUU-IV/2006
} 
Keuangan (BPK), Badan Pemeriksa Keuangan dan Pembangunan (BPKP), ${ }^{6}$ atau akuntan forensik untuk menentukan sumber dan metode penghitungan kerugian keuangan negara. Penghitungan oleh BPK, BPKP atau akuntan forensik itulah yang kemudian dijadikan dasar untuk menyusun surat dakwaan dan surat tuntutan. Apakah hakim akan menerima dan menyetujui sumber dan pola penghitungan kerugian keuangan negara oleh BPK, BPKP atau akuntan forensik, hal itu bergantung kepada keyakinan hakim berdasarkan fakta-fakta/alat bukti yang ada persidangan.

Penentuan sumber dan metode penghitungan kerugian keuangan negara dalam suatu putusan perkara korupsi terkait secara langsung dengan besarnya jumlah uang pengganti yang akan dijatuhkan hakim kepada terdakwa. Terkait dengan hal ini, ada empat kemungkinan yang terjadi. Pertama, hakim menentukan jumlah uang pengganti yang wajib dibayar terpidana setelah terlebih dahulu ditentukan sumber dan metode penghitungan kerugian keuangan negara. ${ }^{7}$ Kedua, hakim menjatuhkan pidana tambahan berupa pembayaran uang pengganti kepada terpidana perkara korupsi, sementara hakim sendiri belum menentukan sumber dan metode penghitungan kerugian keuangan negara. Ketiga, hakim telah menentukan sumber dan metode penghitungan kerugian keuangan negara, tapi pembayaran uang pengganti yang dibebankan kepada terpidana korupsi tidak mengikuti sumber dan metode yang telah ditetapkan. Keempat, penentuan metode penghitungan kerugian keuangan negara tidak mengacu kepada sumber kerugian keuangan negara, sehingga jumlah uang pengganti yang wajib dibayar terpidana korupsi juga mengandung masalah.

Kemungkinan keempat inilah yang ditemukan dalam Putusan Pengadilan Tinggi Tipikor Sulawesi Tenggara Nomor 07/Tipikor/2012/PT. Sulawesi Tenggara dengan terdakwa Chandra Liwang. Dalam perkara ini, terdakwa dinyatakan bersalah melakukan tindak pidana korupsi terkait pengadaan kendaraan roda 4 yaitu Toyota Land Cruiser 4.7 4WD A/T sebanyak 1 (satu) unit dan kendaraan roda empat merk Mitsubishi type Mitsubishi Pajero 3.0 A/T 1 (satu) unit untuk kepentingan menyambut kedatangan presiden 2008 sebesar Rp. 2.265.454.546 yang diketahui dan terbukti fiktif.

\footnotetext{
${ }^{6}$ Hernold Ferry Makawimbang, Kerugian Keuangan Negara dalam Tindak Pidana Korupsi, Suatu Pendekatan Hukum Progresif, Thafa Media, Yogyakarta, 2014, hlm. 49

${ }^{7}$ Pembayaran uang pengganti berdasarkan ketentuan Pasal 18 ayat (1) huruf b Undang-Undang No. 31 Tahun 1999 tentang Pemberantasan Tindak Pidana Korupsi ditempatkan sebagai pidana tambahan. Oleh karena itu, tidak ada keharusan bagi hakim untuk menjatuhkan jenis sanksi tersebut kepada terdakwa yang terbukti melanggar Pasal 2 ayat (1) dan Pasal 3. Bisa saja hakim menyatakan bahwa perbuatan terdakwa menimbulkan kerugian keuangan negara, tapi hakim tidak mewajibkan terdakwa membayar uang pengganti.
} 
Dalam putusannya majelis hakim mewajibkan terdakwa membayar uang pengganti sebanyak Rp. 912.051.546 dengan alasan bahwa Rp. 1.353.403.000 sudah direalisasi oleh terdakwa dalam bentuk pengiriman uang kepada pemegang rekening BCA Nomor 5890064576 milik perusahaan pembelian kendaraan 1 (satu) unit Toyota Land Cruiser 47.4 WD A/T dan 1 (satu) unit Mitsubishi Pajero 3.0 A/ T). Padahal, pengadaan 2 unit roda empat tersebut adalah fiktif. Dengan kata lain, metode penghitungan kerugian keuangan negara yang digunakan majelis hakim adalah selisih antara pencairan dana untuk pengadaan kendaraan dengan realisasi penggunaan dana tersebut. Jelas, metode yang menghasilkan jumlah uang pengganti ini tidak mengacu kepada sumber kerugian keuangan negara berupa aspek pengeluaran (expenditure) dalam bentuk kegiatan fiktif.

\section{Rumusan Masalah}

Berdasarkan latar belakang masalah di atas, permasalahan penelitian dirumuskan sebagai berikut: Pertama, bagaimana sumber kerugian keuangan negara dan metode penghitungannya dalam putusan-putusan pengadilan perkara tindak pidana korupsi? Kedua, apakah terdapat hubungan antara metode penghitungan kerugian keuangan negara dalam pertimbangan hukum hakim dengan penetapan jumlah pembayaran uang pengganti?

\section{Tujuan Penelitian}

Penelitian ini bertujuan untuk mengetahui dan menganalisis: pertama, sumber kerugian keuangan negara dan metode penghitungannya dalam putusan-putusan pengadilan perkara tindak pidana korupsi; dan kedua, kaitan antara metode penghitungan kerugian keuangan negara dalam pertimbangan hukum hakim dengan penetapan jumlah pembayaran uang pengganti.

\section{Metode Penelitian}

Penelitian ini termasuk ke dalam penelitian hukum normatif karena yang dikaji adalah putusan pengadilan khususnya dasar pertimbangan hukum hakim (ratio dedicendi) di dalam menentukan sumber dan metode penghitungan kerugian 
keuangan negara serta keterkaitannya dengan penetapan jumlah pembayaran uang pengganti. ${ }^{8}$

Bahan hukum terdiri atas bahan hukum primeir berupa putusan-putusan pengadilan perkara tindak pidana korupsi Pasal 2 ayat (1) dan Pasal 3 yang telah memiliki kekuatan hukum tetap, ${ }^{9}$ dan bahan hukum sekunder yang berupa bukubuku, jurnal dan hasil penelitian terkait sumber dan metode penghitungan kerugian keuangan negara negara, keuangan negara, dan tindak pidana korupsi. Sedangkan pendekatan yang digunakan ada tiga, yaitu pendekatan perundang-undangan, pendekatan konseptual, dan pendekatan kasus. ${ }^{10}$

Pengumpulan bahan hukum dilakukan melalui studi dokumen putusanputusan pengadilan dan studi pustaka. Sedangkan analisis penelitian berupa analisis deskriptif kualitatif, dalam arti bahan hukum diuraikan dalam bentuk narasi yang tersusun secara sistematis, logis, dan merupakan hasil dari proses interpretasi peneliti terhadap bahan hukum yang dihasilkan berupa dasar pertimbangan hukum hakim dalam menentukan sumber dan metode penghitungan kerugian keuangan negara dalam perkara tindak pidana korupsi dan keterkaitannya dengan penetapan pembayaran uang pengganti. Terdapat tiga alur kegiatan yang terjadi secara bersamaan dalam analisis ini yaitu reduksi data/bahan hukum, penyajian data/ bahan hukum, dan penarikan kesimpulan. ${ }^{11}$

\section{Hasil Penelitian dan Pembahasan}

\section{Sumber dan Metode Penghitungan Kerugian Keuangan Negara, Suatu Sketsa Teoretik dan dalam Putusan-putusan Pengadilan}

Secara teoritik, metode penghitungan kerugian keuangan bergantung kepada sumber kerugian keuangan negara. Dalam tulisan ini, pohon kerugian keuangan negara (fraud tree) yang diperkenalkan The Association of Certified Fraud Examiners

\footnotetext{
${ }^{8}$ Soetandyo Wignjosoebroto, Hukum, Paradigma, Metode dan Dinamika Masalahnya, HuMa, Jakarta, 2002, hlm. 147-176; Ronald Dworkin, Legal Research, Spring, Daedalus, 1973, hlm. 250

${ }^{9}$ Putusan yang dikaji antara lain Putusan Nomor: 01/Pid.Sus/PN.Tipikor Smg dan putusan No. 04/Pid.Sus/ 2011/PN/Sby, putusan Nomor: 32/Pid.Sus/2012/PN. Tipikor. Smg dan putusan Nomor 02/Pid.Sus/2011/PN/ Dps, putusan Nomor: 79/Pid.Sus/2011/PN.Tipikor.Smg, Putusan Nomor: 21/Pid.Sus/2011/PN/Sby, Putusan Nomor 13/Pid.B/Tpk/2011/Pn.Pdg, Putusan Nomor 13/Pid.Sus/2012/P.Tipikor.Dps.

${ }^{10}$ Peter Mahmud Marzuki, Penelitian Hukum, Cetk. Kedua, Prenada Media, Jakarta, 2006; Johnny Ibrahim, Teori dan Metodologi Penelitian Hukum Normatif, Cetakan Kedua, Bayumedia Publishing, Malang, 2006, hlm. 321-32.

${ }^{11}$ Matthew B. Miles dan A. Michael Huberman, Analisis Data Kualitatif, tanpa Penerbit, tt, hlm. 16
} 
(ACFE) di Amerika Serikat dijadikan sebagai basis teoretis metode tersebut. Menurut Theodorus M. Tuanakotta, pohon kerugian keuangan negara memiliki empat cabang (akun). Tiap-tiap akun mempunyai cabang yang menunjukkan hubungan antara perbuatan melawan hukum dengan akun-akun tersebut. Keempat akun tersebut adalah: 1) penerimaan (receipt) yang terdiri atas wajib bayar tidak setor, wajib pungut tidak setor, dan potongan penerimaan ditinggikan; 2) pengeluaran (expenditure) yang terdiri atas kegiatan fiktif, perundangan tidak berlaku lagi, dan pengeluaran lebih cepat; 3) aset (asset) yang terdiri atas pengadaan barang dan jasa, pelepasan aset, pemanfaatan aset, penempatan aset dan kredit macet; dan 4) kewajiban (liability) yang terdiri atas kewajiban nyata, kewajiban bersyarat menjadi nyata dan kewajiban tersembunyi. ${ }^{12}$

Berdasarkan sumber kerugian keuangan negara di atas, metode penghitungan kerugiannya bervariasi antara satu dengan yang lain, sebagaimana tergambar secara rinci pada tabel di bawah ini: ${ }^{13}$

Tabel 1.

Sumber dan Metode Penghitungan Kerugian Keuangan Negara

\begin{tabular}{|c|c|c|}
\hline No. & Sumber Kerugian Keuangan Negara & Metode Penghitungan Kerugian \\
\hline 2 & $\begin{array}{l}\text { Receipt (Penerimaan) } \\
\text { Wajib bayar tidak setor } \\
\text { Wajib pungut tidak setor } \\
\text { Potongan penerimaan ditinggikan } \\
\text { Expenditure (Pengeluaran) } \\
\text { Kegiatan fiktif } \\
\text { Perundangan tidak berlaku lagi } \\
\text { Pengeluaran lebih cepat } \\
\text { Asset (Aset) } \\
\text { Pengadaan barang dan jasa }\end{array}$ & $\begin{array}{l}\text { Pokok dan bunga } \\
\text { Pokok dan bunga } \\
\text { Pokok dan bunga } \\
\text { Pokok dan bunga } \\
\text { Pokok dan bunga } \\
\text { Bunga } \\
\text { Kerugian total (total loss) } \\
\text { Kerugian total dg penyesuaian } \\
\text { Kerugian bersih } \\
\text { Harga realisasi dikurangi harga wajar } \\
\text { Bunga untuk kerugian waktu } \\
\text { Harga realisasi dikurangi harga wajar } \\
\text { Opportunity cost } \\
\text { Kerugian total } \\
\text { Bunga untuk kerugian waktu } \\
\text { Opportunity cost }\end{array}$ \\
\hline
\end{tabular}

${ }^{12}$ Theodorus M. Tuanakotta, Akuntansi Forensike \& Audit Investigatif, Edisi 2, Salemba Empat, Jakarta, 2010 , hlm. 206; Theodorus M. Tuanakotta, Menghitung Kerugian Keuangan Negara dalam Tindak Pidana Korupsi, Salemba Empat, Jakarta, 2009, hlm. 158-171

${ }^{13}$ Ibid., hlm. 182 


\section{Pelepasan Aset dengan Penghitungan Berupa Kerugian Total dengan Penyesuaian ke Bawah dan Kerugian Total}

Sumber kerugian keuangan negara berkaitan dengan pelepasan aset terlihat pada putusan korupsi nomor: 01/Pid.Sus/PN.Tipikor Smg dengan terdakwa Arief Zainuddin, Sekretaris Badan Pelayanan Perijinan Terpadu (BPPT), Kota Semarang, dan putusan No. 04/Pid.Sus/2011/PN/Sby dengan terdakwa HM. Khudlori, selaku Kepala Kantor Pertanahan Kota Surabaya.

Dalam putusan korupsi nomor: 01/Pid.Sus/PN.Tipikor Smg, terdakwa, Juni 2010, membuat surat keputusan atas namanya sendiri dan tanpa izin dari Kepala BPPT Kota Semarang maupun Pemerintah Kota Semarang, bahwa mobil dinas Daihatsu Terios Merk/Type F70ORG-TS berubah hak kepemilikannya menjadi milik terdakwa, sehingga merugikan keuangan negara sebesar Rp. 124.320.000.

Sumber kerugian keuangan negara dalam perkara tersebut terkait aset berupa pelepasan aset. Hal ini karena mobil dinas Daihatsu Terios Merk/Type F70ORGTS, BPKB dan STNKnya yang dilepaskan oleh terdakwa dan berubah menjadi miliknya sendiri pada dasarnya adalah aset yang dimiliki pemerintah Kota Semarang. Sedangkan metode penghitungannya adalah kerugian total dengan penyesuaian ke bawah. ${ }^{14}$ Penentuan metode ini berdasarkan keterangan Yudi Supriyantoro, ahli dari Dinas Perindustrian dan Perdagangan Kota Semarang sebagai berikut: Cara penghitungan harga mobil bukan baru yaitu apabila mobil tersebut masih diproduksi oleh pabrik, maka harga mobil tersebut didasarkan pada daftar harga (price list) dari produsen dengan dihitung penyusutan harganya sebesar $10 \%$ per tahun. Besarnya penyusutan tersebut adalah berdasarkan perkiraan dan survey lapangan. Berdasarkan penghitungan ahli, harga mobil dinas Merk Daihatsu Terios Merk/Type F70ORG-TS, tahun pembuatan 2008, warna hitam, isi slinder 1945 cc, yaitu harga price list $x$ penyusutan $=$ Rp. $153.400 .000,00 \times 20 \%=R p .124 .320 .000,00 .{ }^{15}$

Dalam putusan No. 04/Pid.Sus/2011/PN/Sby, terdakwa menerbitkan dan menandatangai Surat Keputusan Kepala Kantor Pertanahan Kota Surabaya Nomor: 196-550.135.1-2007 tanggal 01 Maret 2007 tentang Pemberian Hak Guna Bangunan atas nama Handoko Soelayman atas tanah di Jalan Marmoyo No. 2 kelurahan Darmo

\footnotetext{
${ }^{14}$ Metode ini sama dengan kerugian bersih. Pada kasus pembelian suku cadang mesin dan alat berat dari negara lain, jika ternyata barang mesin dan alat berat tersebut rusak dan tinggal barang rongsokan karena suku cadangnya tidak diproduksi lagi, maka metode penghitungannya adalah kerugian keuangan negara hanyalah sejumlah kerugian bersih, yaitu kerugian total dikurangi nilai bersih barang rongsokan tersebut.

${ }^{15}$ Putusan hlm. 51-52.
} 
Kecamatan Wonokromo Kota Surabaya. Atas dasar surat tersebut, terbitlah Sertifikat Hak Guna Bangunan Nomor 738 tangal 08 Maret 2007 atas nama Handoko Soelayman di atas tanah yang sebenarnya milik PT. Pertamina (Persero) c.q Pertamina Unit Pemasaran V Surabaya d/h Unit Pembekalan Marmoyo Nomor 2, kelurahan Darmo Kecamatan Wonokromo Kota Surabaya. Akibatnya, negara mengalami kerugian sebesar Rp. 9.757.710.000.

Sumber kerugian keuangan negara dalam perkara tersebut terkait aset berupa pelepasan aset. Sebab tanah tersebut merupakan tanah/aset yang secara sah dimiliki oleh negara, yakni PT. Pertamina, yang tidak boleh dilepaskan kepada pihak ketiga tanpa dasar hukum yang jelas. Sedangkan metode penghitungannya adalah kerugian total, yakni sebesar 9.757.710.000. Angka tersebut didasarkan pada Surat Pemberitahuan Pajak Terutang Pajak Bumi Bangunan Tahun 2007 yang dibuat dan ditandatangani Kepala Kantor Pajak Bumi dan Bangunan Surabaya 02 Januari 2007 bahwa Nilai Jual Obyek Pajak per meter persegi untuk Bumi atas tanah di jalan Marmoyo Nomor 2, kelurahan Darmo Kecamatan Wonokromo Kota Surabaya sebesar Rp. 8.145.000. Karena tanah tersebut seluas 1198m2, maka 8.145.000 dikalikan 1198m2 menjadi 9.757.710.000.

\section{Kegiatan Fiktif dengan Penghitungan berupa Kerugian/Biaya Pokok}

Sumber kerugian keuangan negara berkaitan dengan kegiatan fiktif ada pada putusan Nomor: 32/Pid.Sus/2012/PN. Tipikor. Smg dengan terdakwa M. Yaeni bin Sukiman, Ketua DPRD Kabupaten Grobogan periode 2004-2009, dan putusan Nomor 02/Pid.Sus/2011/PN/Dps dengan terdakwa I Gusti Ngurah Putu Ambara, Pejabat Pelaksana Teknis Kegiatan (PPTK) dengan Keputusan Kepala Dinas Pariwisata Provinsi Bali.

Dalam putusan Nomor: 32/Pid.Sus/2012/PN. Tipikor Smg, terdakwa dan beberapa anggota DPRD lainnya menggunakan sebagian dana anggaran pemeliharaan alat angkutan darat bermotor dan kendaraan dinas bermotor tahun 2006-2008 untuk membayar angsuran kredit sepeda motor, membayar kartu hallo, membayar kekurangan gaji, bon uang tunai, serta untuk kegiatan-kegiatan yang tidak dapat dipertanggungjawabkan pengeluaran dananya, sehingga negara dirugikan sebesar Rp. 1.959.457.343.

Dalam perkara ini, sumber kerugian keuangan negara terkait pengeluaran (expenditure) berupa kegiatan fiktif. Hal ini karena dana-dana untuk kepentingan 
pribadi terdakwa diambilkan bukan dari uang pribadi terdakwa, melainkan dari uang pemerintah Kota Grobogan, dan seakan-akan kegiatan tersebut atas nama kegiatan dinas. Sedangkan metode penghitungannya adalah biaya pokok tanpa bunga, yaitu sebesar Rp. 1.959.457.343. ${ }^{16}$ Sekalipun jumlah kerugian keuangan negara dalam perkara ini sebesar Rp. 1.959.457.343, namun karena pelaku delik dalam perkara ini tidak hanya terdakwa M. Yaeni bin Sukiman saja, tapi juga beberapa anggota DPRD Kabupaten Grobogan Periode 2004-2009 yang lain, maka kerugian keuangan negara yang dibebankan kepada terdakwa hanya kerugian keuangan negara yang terjadi akibat dipergunakan untuk kepentingan pribadi. Masalah muncul ketika dalam pertimbangan hukum hakim terdapat dua jumlah kerugian keuangan negara yang dinikmati oleh terdakwa, yaitu Rp. 611.171.574 berdasarkan penghitungan kerugian keuangan negara ahli akuntansi dan auditing, Luciana Marlyn Haryanti, ${ }^{17}$ dan Rp. 270.870 .117 yang tidak diketahui dari mana angkat tersebut muncul. ${ }^{18}$

Dalam putusan Nomor 02/Pid.Sus/2011/PN/Dps, terdakwa mengajukan usulan pencairan dana anggaran sebesar Rp. 297.570 .000 untuk pelaksanaan kegiatan WTM (World Travel Market) London tahun 2008. Dalam laporannya, dana tersebut telah digunakan oleh terdakwa untuk kegiatan-kegiatan; 1) perjalanan Dinas Rp. 165.120.000; 2) sewa booth Rp. 120.804.000; 3) registration fee Rp. 8.688.000, sehingga masih ada sisa dana sebesar Rp 2.958.000 dan telah disetor menjadi sisa kas Bendahara Pengeluaran. Padahal Departemen Kebudayaan dan Pariwisata tidak mengeluarkan dana sewa booth karena sudah dibayarkan sebelumnya, namun oleh terdakwa dana Rp. 120.804.000 tersebut seolah-olah digunakan untuk kegiatan sewa smooth dengan cara melampirkan Official Recive tertanggal 25 September 2008 dan Invoice for Raw Space Rental tertanggal 25 September 2008. Akibatnya, negara mengalami kerugian Rp. 97.741.704,00.

Sumber kerugian keuangan negara dalam perkara tersebut terkait pengeluaran berupa kegiatan fiktif. Hal ini karena uang Rp. 97.741.704 seharusnya dimasukkan ke kas Propinsi Bali, tapi hal itu tidak dilakukan terdakwa. Terdakwa malah melampirkan Official Recive tertanggal 25 September 2008 dan Invoice for Raw Space Rental tertanggal 25 September 2008 seakan-akan kegiatan untuk sewa booth memang

\footnotetext{
${ }^{16}$ Putusan hlm. 100-101 dan hlm. 169

${ }^{17}$ Putusan hlm. 155

${ }^{18}$ Putusan hlm. 170
} 
ada, padahal kegiatan itu fiktif belaka. Sedangkan metode penghitungannya adalah biaya pokok yakni Rp. 97.741.704. ${ }^{19}$

\section{Wajib Bayar Tidak Setor dengan Penghitungan berupa Kerugian/Biaya Pokok Ditambah Bunga}

Sumber kerugian keuangan negara terkait dengan aspek pemasukan berupa wajib bayar tidak setor adalah putusan Nomor: 79/Pid.Sus/2011/PN.Tipikor.Smg, dengan terdakwa Kushardjono bin Koesnindar Hadi Soeharto, Sekretaris Daerah (Sekda) Kabupaten Sragen. ${ }^{20}$ Sebagai kepala Kepala Badan Pengelola Keuangan Daerah (BPKD) Kabupaten Sragen, terdakwa menempatkan Dana Kas Daerah pada PD BPR Djoko Tingkir dalam bentuk surat berharga berupa Bilyet Deposito sebesar Rp. 36.376.500.000.

Dalam pelaksanaanya, Bilyet Deposito tersebut tidak disimpan sebagai Surat Berharga milik Pemerintah Kab. Sragen namun secara bertahap digunakan untuk dijadikan jaminan pinjaman Pemerintah Kabupaten Sragen oleh pejabat Pemerintah Kab. Sragen pada PD BPR Djoko Tingkir. Bahkan atas penggunaan Bilyet Deposito, terdakwa membuat surat pernyataan 14 Agustus 2004 bahwa semua Deposito atas nama Bupati Sragen QQ BPKD Kab. Sragen digunakan sebagai jaminan pinjaman di PD BPR Djoko Tingkir Kab. Sragen tidak akan diambil dan dicairkan sebelum pinjamannya lunas. Uang hasil pinjaman tersebut oleh terdakwa dan Untung Sarono Wiyono Sukarno maupun Sri Wahyuni tidak pernah dimasukkan ke Kas Daerah, tetapi langsung dipergunakan untuk keperluan di luar kepentingan Pemerintah Kab. Sragen. Terdakwa juga mendapatkan pinjaman dari PD BPR Karangmalang Rp. 6.134.000.000. Akibatnya, negara mengalami kerugian sebesar Rp. 42.510.200.000.

Sumber kerugian keuangan negara di atas mengenai penerimaan berupa wajib bayar tidak setor. Seharusnya uang sebesar Rp. 36.376.500.000 yang dipinjam dari PD BPR Djoko Tingkir disetorkan oleh terdakwa kepada pemerintah Kab. Sragen, tetapi uang itu oleh terdakwa digunakan untuk kepentingan pribadi terdakwa sendiri dan Untung Wiyono. ${ }^{21}$ Dalam perkembangannya, dari uang sejumlah Rp. 36.376.500.000 yang dipinjam terdakwa dari PD BPR Djoko Tingkir, terdapat uang

\footnotetext{
${ }^{19}$ Putusan hlm. 90.

${ }^{20}$ Selaku Sekda, terdakwa memiliki tugas sebagai koordinator Pengelolaan Keuangan Daerah, dengan tugas pokok dan fungsi terdakwa membantu kepala daerah menyusun kebijakan dan mengkoordinasikan penyelenggaraan urusan pemerintahan daerah termasuk pengelolaan keuangan daerah.

${ }^{21}$ Putusan hlm. 239.
} 
sejumlah Rp. 11.216.252.352 yang telah jatuh tempo dan berstatus macet terdiri dari pinjaman pokok sebesar Rp. 11.007.600 dan bunga pinjaman sebesar Rp. 208.652.352. ${ }^{22}$ Sedangkan metode penghitungannya adalah biaya pokok ditambah bunga yakni Rp. 11.216.252.352 meliputi biaya pokok Rp. 11.007.600 dan bunga Rp. 208.652.352.

\section{Pengeluaran yang Tidak Sesuai dengan Anggaran dengan Penghitungan Berupa Selisih Jumlah Dana Anggaran dengan Jumlah Realisasi.}

Terdapat dua putusan pengadilan perkara tindak pidana korupsi yang sumber kerugian keuangan negara berkaitan dengan pengeluaran yang tidak sesuai dengan anggaran karena digunakan untuk kepentingan pribadi terdakwa. Pertama, putusan Nomor: 21/Pid.Sus/2011/PN/Sby, dengan terdakwa Yusus Soemarno, wiraswasta. Tahun 2008 anggaran dana untuk bantuan sosial Provinsi Jawa Timur sebesar Rp. 570.531.794.904, sedangkan untuk Kabupaten Bondowoso terdapat 14 lembaga penerima Bantuan Dana Sosial dari Provinsi Jawa Timur dengan nilai sebesar Rp. 1.655.000.000. Dari Rp. 830.000.000 yang disetujui, sejumlah Rp. 608.065.000 tidak diberikan kepada lembaga penerima bantuan sosial melainkan digunakan untuk kepentingan pribadi terdakwa dan M. Pudjiarto.

Sumber kerugian keuangan negara dalam perkara di atas terkait pengeluaran yang tidak sesuai dengan anggaran dan digunakan untuk kepentingan pribadi terdakwa dan M. Pudjiarto. Seharusnya, uang sebesar Rp. 830.000.000 tersebut diberikan semua kepada lembaga penerima bantuan sosial di Kabupaten Bondowoso dari Propinsi Jawa Timur, tapi oleh terdakwa hanya diberikan sebesar Rp. 221.935.000. Sedangnya sisanya yakni sebesar Rp. 608.065.000 digunakan untuk kepentingan pribadi terdakwa dan M. Pudjiarto. Sedangkan metode penghitungannya adalah jumlah selisih antara anggaran dana yang seharusnya diberikan kepada lembaga penerima bantuan sosial dikurangi jumlah realisasi berdasarkan bukti-bukti yang sah dan dapat dipertanggungjawabkan. Secara lebih rinci, metode penghitungan kerugian keuangan negara dalam perkara ini sebagai berikut: ${ }^{23}$

\footnotetext{
${ }^{22}$ Putusan hlm. 240.

${ }^{23}$ Putusan hlm. 87, 107 dan 110 .
} 
Tabel 2.

Metode Penghitungan Kerugian Keuangan Negara

\begin{tabular}{|ll|r|r|r|}
\hline No & \multicolumn{1}{|c|}{ Nama Lembaga } & Sesuai LPJ & Hasil Audit & Selisih \\
\hline 1 & Karangtaruna Perkasa & 100.000 .000 & 24.550 .000 & 75.450 .000 \\
2 & Karangtaruna Kartini & 100.000 .000 & 21.835 .000 & 78.165 .000 \\
3 & Karangtaruna Putra Bangsa & 100.000 .000 & 24.250 .000 & 78.750 .000 \\
4 & Panitia Pembangunan SMU Darul Fikri & 150.000 .000 & 45.000 .000 & 105.000 .000 \\
& $\begin{array}{l}\text { Panitia Gerakan Menanam Pohon dan } \\
5\end{array}$ Cinta Lingkungan & 200.000 .000 & 55.150 .000 & 144.850 .000 \\
& $\begin{array}{l}\text { Panitia Gerakan Penghijauan dan } \\
6\end{array}$ Cinta Lingkungan & 180.000 .000 & 221.935 .000 & 128.850 .000 \\
\hline \multicolumn{2}{|l}{} & 830.000 .000 & 221.935 .000 & 608.065 .000 \\
\hline
\end{tabular}

Kedua, Putusan Nomor 13/Pid.B/Tpk/2011/Pn.Pdg, dengan terdakwa Maulida Gustina, Kapolres Agam. Terdakwa menggunakan dana penyelidikan, penyidikan dan Binamitra Polres Agam yang terdapat di dalam DIPA TA. 2009-2010 untuk kepentingan pribadinya sebesar Rp. 378.166.611, sedangkan sisanya sebesar Rp. 385.989.339 tidak didukung dengan bukti pertanggungjawaban keuangan. Akibatnya, negara mengalami kerugian Rp. 764.156 .000 dengan rincian 378.166.611 digunakan terdakwa untuk kepentingan pribadinya dan 385.989.339 tidak didukung dengan bukti pertanggungjawaban keuangan, atau menurut Badan Pemeriksa Keuangan RI terdapat sejumlah uang Rp. 598.439.389 yang tidak dapat dipertanggungjawabkan oleh terdakwa.

Dalam perkara ini, sumber kerugian keuangan negara mengenai pengeluaran yang tidak sesuai dengan anggaran dan digunakan untuk kepentingan pribadi terdakwa. Sedangkan metode penghitungannya adalah jumlah selisih antara anggaran dana untuk penyelidikan, penyidikan dan Binamitra Polres Agam yang seharusnya dikeluarkan dikurangi jumlah dana yang digunakan terdakwa untuk kepentingan pribadinya dan dana-dana yang yang tidak didukung degnan pertanggungjawaban keuangan. Hal yang menarik dalam perkara ini adalah ketika menghitung dana yang tidak dapat dipertanggungjawabkan keuangannya karena tidak didukung dengan bukti-bukti yang kuat dan memadai. Menurut perhitungan ahli dari BPKP, jumlah dana yang tidak dapat dipertanggungjawabkan keuangannya sebesar Rp. 385.989.339, sedangkan menurut perhitungan ahli dari BPK, jumlah dana yang tidak dapat dipertanggungjawabkan keuangannya sebesar Rp. 598.439.389. 


\section{Hubungan antara Sumber dan Metode Penghitungan Kerugian Keuangan Negara dengan Penetapan Jumlah Uang Pengganti}

Dalam menentukan pembayaran jumlah uang pengganti, majelis hakim dalam perkara korupsi nomor: 01/Pid.Sus/PN.Tipikor Smg sebenarnya menghubungkannya dengan metode penghitungan kerugian keuangan negara. Sekalipun terdakwa tidak dijatuhi pidana tambahan berupa pembayaran uang pengganti, tapi karena mobil dinas Daihatsu Terios Merk/Type F70ORG-TS seharga Rp. 124.320.000 telah dikembalikan kepada Pemerintah Kota Semarang, maka terdakwa tidak perlu lagi dibebani kewajiban membayar uang pengganti sejumlah Rp. 124.320.000. ${ }^{24}$ Demikian juga dalam perkara korupsi No. 04/Pid.Sus/2011/PN/Sby. Hakim tidak menjatuhkan pidana tambahan berupa pembayaran uang pengganti sebesar Rp. 9.757.710.000 sebagai kerugian total akibat perbuatan terdakwa. Hal ini karena tanah seluas $1198 \mathrm{~m}^{2}$ dan sertifikatnya dikembalikan dan menjadi milik Badan Pertanahan Kota Surabaya, maka tanah tersebut secara resmi masih menjadi hak milik PT. Pertamina. Dengan demikian, ada keterkaitan antara penetapan pembayaran uang pengganti dengan metode penghitungan kerugian keuangan negara.

Dalam perkara korupsi Nomor: 32/Pid.Sus/2012/PN. Tipikor. Smg, majelis hakim tidak menghubungkan antara jumlah uang pengganti dengan sumber kerugian keuangan negara. Dalam amar putusannya, hakim menyatakan bahwa jumlah uang pengganti yang wajib dibayar terdakwa sebesar Rp. 187.363.574, padahal kerugian keuangan negara sebesar Rp. 611.171.574 atau Rp. 270.870.117. Dasar pertimbangannya adalah bahwa 'pidana tambahan berupa pembayaran uang pengganti jumlah pembayarannya tidak equivalent dengan 'kerugian keuangan negara' dan sebanyak-banyaknya sama dengan harta benda yang diperoleh dari tindak pidana korupsi yang dilakukan'. ${ }^{25}$

Pertimbangan di atas menunjukkan bahwa frase 'sebanyak-banyaknya sama dengan harta benda yang diperoleh dari tindak pidana yang dilakukan' mengandung arti bahwa hakim boleh saja menjatuhkan pidana tambahan berupa pembayaran uang pengganti yang jumlahnya lebih kecil dari jumlah kerugian keuangan negara yang secara riil maupun potensiil diperoleh terdakwa. Hal yang tidak boleh dilakukan hakim adalah menjatuhkan pidana tambahan berupa pembayaran uang pengganti yang jumlahnya lebih besar dari jumlah kerugian keuangan negara yang

\footnotetext{
${ }^{24}$ Putusan hlm. 81-82.

${ }^{25}$ Putusan hlm. 171.
} 
secara riil diperoleh terdakwa. Namun demikian, sekalipun hakim diperbolehkan menjatuhkan pidana tambahan berupa pembayaran uang pengganti yang jumlahnya lebih kecil dari jumlah kerugian keuangan negara yang secara riil maupun potensiil diperoleh terdakwa, hal itu harus diperkuat dengan alasan-alasan hukum yang argumentatif, sehingga tidak timbul kesan bahwa penentuan jumlah pembayaran uang pengganti bergantung kepada selera hakim, karena jika hal itu terjadi, putusan hakim akan menjadi liar dan sewenang-wenang. Dalam konteks inilah, penulis sama sekali tidak menemukan alasan mengapa hakim menentukan jumlah pembayaran uang pengganti lebih rendah/kecil dari jumlah kerugian keuangan negara yang dipergunakan terdakwa untuk kepentingan pribadinya.

Dalam putusan Nomor 02/Pid.Sus/2011/PN/Dps, sekalipun kerugian keuangan negara dalam perkara ini sebesar Rp. 97.741.704, namun jumlah tersebut tidak dibebankan semuanya kepada terdakwa karena yang menikmati uang sejumlah Rp. 97.741.704 tidak hanya terdakwa tapi juga Gede Nurjaya yang diperiksa dalam perkara lain. ${ }^{26}$ Jadi, kewajiban terdakwa untuk membayar uang pengganti tidak sebesar Rp. 97.741.704, tapi sebesar Rp 48.870.852. Angka tersebut muncul setalah kerugian keuangan negara sebesar Rp. 97.741.704 dibagi menjadi dua masingmasing Rp. 48.870 .852 menjadi kewajiban terdakwa dan Gede Nurjaya.

Dalam putusan Nomor: 79/Pid.Sus/2011/PN.Tipikor.Smg, sekalipun ada korelasi antara sumber kerugian keuangan negara dengan metode penghitungannya, namun dalam perkara ini majelis hakim tidak menjatuhkan pidana tambahan berupa pembayaran uang pengganti. Fakta-fakta hukum persidangan memang telah menunjukkan dan menyebutkan bahwa kerugian keuangan negara akibat perbuatan terdakwa sebesar Rp. 11.216.252.352 meliputi kerugian pokok ditambah bunga, namun hal itu tidak cukup bagi majelis hakim untuk menjatuhkan pidana tambahan berupa pembayaran uang pengganti kepada terdakwa.

Terdapat tiga alasan mengapa hal itu terjadi. Pertama, Jaksa Penuntut Umum sejak awal tidak memasukkan Pasal 18 Undang-Undang Nomor 31 Tahun 1999 jo Undang-Undang Nomor 20 Tahun 2001 tentang Pemberantasan Tindak Pidana Korupsi mengenai eksistensi pidana tambahan berupa pembayaran uang pengganti sebagai salah satu basis hukum untuk mendakwa terdakwa. Tidak diketahui dengan pasti alasan Jaksa Penuntut Umum tidak memasukkan pasal tersebut. Kedua, karena Jaksa Penuntut Umum tidak memasukkan Pasal 18 tersebut, hakim juga tidak

${ }^{26}$ Putusan hlm. 94. 
menjatuhkan pidana tambahan berupa pembayaran uang pengganti kepada terdakwa. Ketiga, hakim memaknai bahwa pembayaran uang pengganti hanya bisa dijatuhkan kepada terdakwa jika ia telah memperoleh harta benda yang berasal dari tindak pidana korupsi yang dilakukannya. Disebutkan dalam satu satu pertimbangan hukum hakim sebagai berikut: ${ }^{27}$

Menimbang, bahwa berdasarkan fakta hukum yang terungkap dipersidangan, Majelis memperoleh fakta bahwa benar terdakwa sama sekali tidak ada memperoleh harta benda dari tindak pidana korupsi yang dilakukannya, sedangkan ketentuan Pasal 18 Undang-undang Nomor 31 tahun 1999 jo Undangundang Nomor 20 tahun 2001 tentang Pemberantasan Tindak Pidana Korupsi menentukan bahwa pidana tambahan berupa membayar uang pengganti hanya dapat dijatuhkan terhadap terdakwa yang terbukti melakukan tindak pidana korupsi dan memperoleh harta benda yang berasal dari tindak pidana yang dilakukannya tersebut, oleh karenanya dalam perkara ini terhadap diri Terdakwa tidak akan dijatuhkan pidana tambahan sebagaimana diatur dalam ketentuan Pasal 18 Undang-undang Nomor 31 tahun 1999 jo Undang-undang Nomor 20 tahun 2001 tentang Pemberantasan Tindak Pidana Korupsi.

Dalam menetapkan pembayaran uang pengganti wajib dibayar oleh terdakwa, majelis hakim dalam perkara Nomor: 21/Pid.Sus/2011/PN/Sby ini sepenuhnya mengikuti metode penghitungan kerugian keuangan negara. Jumlah kerugian keuangan negara dalam perkara ini sebesar Rp. 608.065.000, namun karena sebagian dari uang tersebut telah dikembalikan oleh terdakwa sebesar Rp. 27.065.000, maka jumlahnya berkurang menjadi Rp. 581.000.000. Dalam menentukan jumlah uang pengganti yang wajib dibayar terdakwa, majelis hakim membagi angka Rp. 581.000.000 tersebut menjadi dua yakni sebesar Rp. 290.500.000, masing-masing dibebankan kepada terdakwa dan M. Pudjiarto. ${ }^{28}$

Dalam putusan Nomor 13/Pid.B/Tpk/2011/Pn.Pdg, penetapan jumlah uang pengganti oleh hakim hanya berpedoman pada jumlah uang yang dipergunakan terdakwa untuk kepentingan pribadinya, yakni sebesar Rp. 378.166.611. Namun karena berdasarkan fakta-fakta hukum yang terungkap dalam persidangan, terdakwa telah mengembalikan keuangan negara yang telah digunakan untuk kepentingan pribadinya sebesar Rp. 200.000.000, ${ }^{29}$ maka terdakwa hanya dibebani kewajiban membayar uang pengganti sebesar Rp. 178.166.611.30

\footnotetext{
${ }^{27}$ Putusan hlm. 254

${ }^{28}$ Putusan hlm. 117

${ }^{29}$ Putusan hlm. 136

${ }^{30}$ Putusan hlm. 140 dan 143
} 
Masalahnya adalah bahwa dalam satu pertimbangan hukum hakim disebutkan secara eksplisit sebagai berikut: ${ }^{31}$

Menimbang, bahwa menurut majelis yang menimbulkan kerugian keuangan negara dalah kegiatan-kegiatan yang dilakukan oleh terdakwa yang tidak dianggarkan dalam DIPA tahun 2009/2010 di Polres Agama serta pelaksanaan kegaitan yang tidak didukung oleh bukti pertanggungjawaban keuangan oleh terdakwa selaku kuasa pengguna anggaran.

Jika majelis hakim konsisten dengan pertimbangan hukumnya, seharusnya jumlah uang pengganti yang wajib dibayar oleh terdakwa karena hal itu merupakan keuangan negara tidak hanya sebesar Rp. 178.166.611, tapi sebesar Rp. 564.155.950 jika mengikuti perhitungan BPKP atau sebesar Rp. 776.606 .000 jika mengikuti perhitungan BPK RI. Dengan demikian, penetapan jumlah pembayaran uang pengganti dalam perkara ini tidak terkait dengan metode penghitungan kerugian keuangan negara.

\section{Penutup}

Berdasarkan hasil penelitian dan pembahasan di atas, sumber dan metode penghitungan kerugian keuangan negara bervariasi, antara lain; a) pelepasan aset dengan penghitungan berupa kerugian total dengan penyesuaian ke bawah; b) kegiatan fiktif dengan penghitungan berupa kerugian/biaya pokok; c) wajib bayar tidak setor dengan penghitungan berupa kerugian/biaya pokok ditambah bunga; d) pengeluaran yang tidak sesuai dengan anggaran dengan penghitungan berupa jumlah selisih antara anggaran dana yang seharusnya diberikan kepada lembaga penerima bantuan sosial dikurangi jumlah realisasi berdasarkan bukti-bukti yang sah dan dapat dipertanggungjawabkan.

Dalam menetapkan pembayaran jumlah uang pengganti, terdapat tiga putusan yang tidak mengkaitkannya dengan metode penghitungan kerugian keuangan negara, yakni putusan korupsi Nomor: 32/Pid.Sus/2012/PN. Tipikor. Smg, putusan Nomor: 79/Pid.Sus/2011/PN.Tipikor.Smg, dan putusan Nomor 13/Pid.B/Tpk/ 2011/Pn.Pdg. Alasannya, hakim boleh menetapkan jumlah uang pengganti yang jumlah di bawah jumlah kerugian keuangan negara, jaksa penuntut umum tidak mencantumkan Pasal 18 ayat (1) huruf b baik dalam surat dakwaan maupun dalam

\footnotetext{
${ }^{31}$ Putusan hlm. 139
} 
surat tuntutan, dan hakim tidak memasukkan jumlah uang yang tidak dapat dipertanggungjawabkan keuangannya baik berdasarkan perhitungan dari BPKP maupun BPK padahal keduanya diakui terbukti.

\section{Daftar Pustaka}

Ali, Mahrus, Asas, Teori dan Praktik Hukum Pidana Korupsi, UII Press, Yogyakarta, 2013.

B. Miles, Matthew dan A. Michael Huberman, Analisis Data Kualitatif, tanpa Penerbit, tt.

Basuki Minarno, Nur, Penyalahgunaan Wewenang dan Tindak Pidana Korupsi dalam Pengelolaan Keuangan Daerah, Cetk. Kedua, LaksBang Mediatama, Yogyakarta, 2009.

Chazawi, Adami, Hukum Pidana Materiil dan Formil Korupsi di Indonesia, Cetk. Kedua, Bayumedia Publishing, Malang, 2005.

Ferry Makawimbang, Hernold, Kerugian Keuangan Negara dalam Tindak Pidana Korupsi, Suatu Pendekatan Hukum Progresif, Thafa Media, Yogyakarta, 2014.

Ibrahim, Johnny, Teori dan Metodologi Penelitian Hukum Normatif, Cetk. Kedua, Bayumedia Publishing, Malang, 2006.

M. Tuanakotta, Theodorus, Akuntansi Forensik $\mathcal{E}$ Audit Investigatif, Edisi 2, Salemba Empat, Jakarta, 2010.

, Menghitung Kerugian Keuangan Negara dalam Tindak Pidana Korupsi, Salemba Empat, Jakarta, 2009.

Mahmud Marzuki, Peter, Penelitian Hukum, Cetk. Kedua, Prenada Media, Jakarta, 2006

Wignjosoebroto, Soetandyo, Hukum, Paradigma, Metode dan Dinamika Masalahnya, HuMa, Jakarta, 2002.

Undang-Undang Nomor. 1 Tahun 2004 tentang Perbendaharaan Negara

Undang-Undang Nomor. 31 tahun 1999 jo Undang-undang Nomor 20 Tahun 2001 tentang Pemberantasan Tindak Pidana Korupsi

Putusan Mahkamah Konstitusi Nomor 003/PUU-IV/2006

Putusan No. 04/Pid.Sus/2011/PN/Sby

Putusan Nomor 02/Pid.Sus/2011/PN/Dps,

Putusan Nomor 13/Pid.B/Tpk/2011/Pn.Pdg

Putusan Nomor: 01/Pid.Sus/PN.Tipikor Smg

Putusan Nomor: 21/Pid.Sus/2011/PN/Sby 
Putusan Nomor: 32/Pid.Sus/2012/PN. Tipikor. Smg

Putusan Nomor: 79/Pid.Sus/2011/PN.Tipikor.Smg

Ronald Dworkin, Legal Research, Spring, Daedalus, 1973. 